\title{
18
}

\section{The Fiscal Responsibility Act 1994: How a nonbinding policy instrument proved highly powerful}

\author{
Derek Gill
}

\section{Introducing the Fiscal Responsibility Act}

Sir Robert Muldoon, New Zealand's prime minister from 1975 to 1984, was recorded as observing that 'most people wouldn't recognise a Budget deficit if they fell over it in the street' (Kerr 2008: 3). While that statement might have applied to New Zealand at the time, it would not be made about contemporary New Zealand, where the major parties compete for the fiscal responsibility label. The fiscal responsibility provisions in the New Zealand Public Finance Act 1989 (introduced as the Fiscal Responsibility Act or FRA) have become an enduring part of New Zealand's public management regime since coming into force in 1994. Fiscal responsibility provides the foundation for the Treasury's budgeting process, is embedded in the wider political discourse and is now part of New Zealand's constitutional arrangements. The FRA is one of the significant factors that help explain the success of successive administrations in running

1 The author would like to acknowledge the key people involved in the FRA who made themselves available for interview. Any errors or omissions remain the responsibility of the author. The author was working for the Treasury at the time of the development of the FRA and was a senior official at the State Services Commission at the time of the 2004 Public Finance Act amendments but was not directly involved in either process. 
sustained structural fiscal surpluses and reducing net public debt from a peak in 1992 of just less than 50 per cent of GDP to close to zero by 2006 (Figure 18.1).

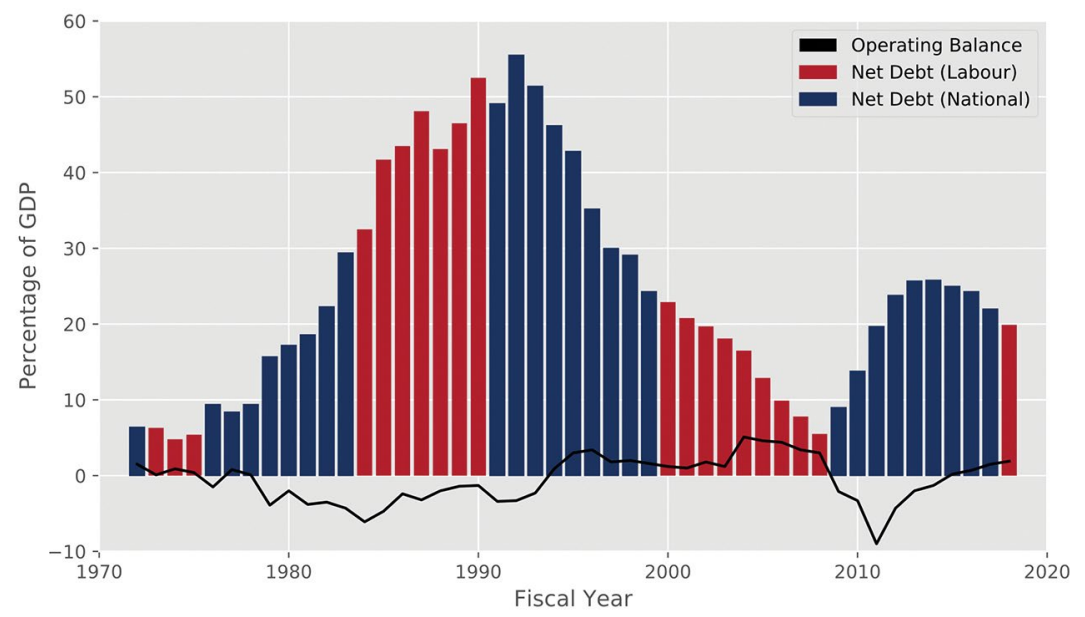

Figure 18.1 New Zealand Government net debt and fiscal balance, 1970-2018

Source: NZIER (n.d.).

While the FRA was not the catalyst-as the improvement in New Zealand's fiscal position pre-dates its enactment-the Act was an effective commitment device (Boston 2016) that helped cement fiscal discipline in New Zealand. In addition, the $F R A$ was flexible enough to accommodate the recession of 2008-10 and the fiscal impact of the Canterbury earthquake sequence, while ensuring New Zealand returned to a fiscally sustainable track (see Figure 18.2). Arguably, the GFC, Canterbury earthquakes and the Kaikoura earthquake have also helped cement the cross-party political commitment to fiscal discipline-in other words, regular 'external' shocks continue to remind policymakers of New Zealand's economic vulnerability.

In preparation for the 2017 general election, the opposition Labour and Green parties publicly committed themselves to Budget responsibility rules. These were subsequently included largely word-for-word in the 2018 Budget Policy Statement (BPS) and in the first Budget of the new Labour-Green-New Zealand First Coalition Government. These rules included a commitment to keeping spending below 30 per cent of GDP, running an operating surplus over the cycle and reducing net debt to below 20 per cent of GDP by 2022 . 


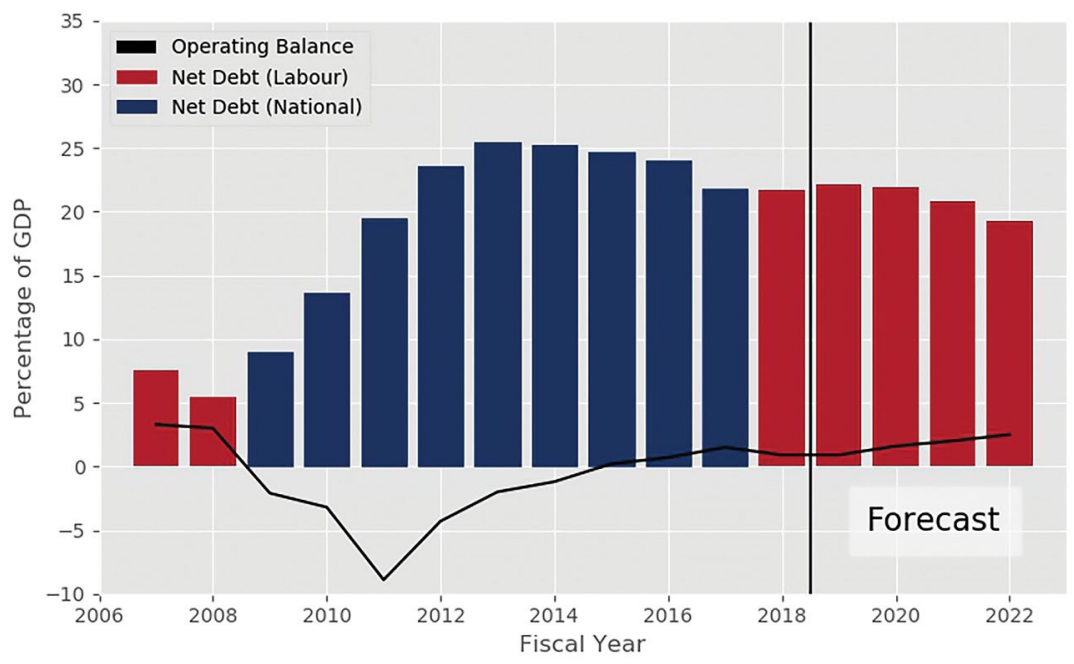

Figure 18.2 The recent track and outlook for the operating balance and net public debt, 2006-22

Source: The Treasury (2018).

New Zealand was a pathfinder on fiscal responsibility and the success of the FRA in making fiscal responsibility an active part of everyday political discourse is striking given the mixed record of most countries' experiences with legislated targets for Budget balances, spending and debt of various sorts. It is even more striking given the relatively arcane and technical nature of the FRA provisions (discussed in Box 18.1) and the lack of overt legal penalties for breaching the rules. The surprising success of a weak, nonbinding policy instrument is because it has political force even if it is not legally enforceable. In essence, the FRA:

1. Makes the government of the day responsible for articulating how it proposes to operationalise the principles of fiscal responsibility when developing its Budget (the principles are detailed in Box 18.1 and include targets for net debt levels and a balanced Budget over the business cycle).

2. Requires the Treasury to provide twice-yearly independent economic and fiscal updates, including specified ex-ante information on the fiscal strategy, the current economic conditions and fiscal outlook and risks to that outlook, a preelection update, the outlook over 10 years and every four years over a 40 -year term. 
3. Gives the Secretary of the Treasury an independent statutory role in ex-ante and ex-post financial reporting based on generally accepted accounting principles (GAAP). These principles are set by an independent accounting standards body, as the accounting framework for all ex-ante and ex-post fiscal reporting minimises the scope for 'creative accounting'.

Box 18.1 The principles of responsible fiscal management

The principles of responsible fiscal management, incorporated since 2004 in the Public Finance Act of 1989, require governments to:

- Ensure the achievement and subsequent maintenance of 'prudent levels' of public debt, by running operating balances that, on average over time, are non-negative and consistent with the desired trajectory of the debt.

- Achieve and maintain levels of the Crown's net worth that provide an adequate buffer against potential future events adversely impacting the Crown's balance sheet.

- Manage prudently the fiscal risks facing the government.

- Pursue policies consistent with reasonable stability and predictability of tax rates.

In 2013, the principles were amended to incorporate considerations relating to:

- the interaction between fiscal and monetary policies

- the likely impact of any fiscal strategy on present and future generations

- the efficiency and fairness of the tax system

- the effectiveness and efficiency in management of the Crown's resources.

The emphasis on greater openness and transparency increases the focus on more strategic and long-term fiscal issues, relative to short-term and political factors. In addition, the FRA offers escape clauses ('safety valves') for cyclical fluctuations or systemic events such as natural disasters. This ensures the government of the day has discretion about how it applies the principles in the face of changing circumstances.

\section{A tripartite success?}

Budgeting is simultaneously an inherently political process and a technocratic exercise. The FRA has succeeded at both levels. At the technocratic level, the FRA has been a programmatic success as New Zealand's fiscal aggregates have been turned around since the early 1990s, with large structural operating fiscal surpluses, as shown in Figure 18.1, until the period of the GFC. Figure 18.1 also shows how, until 2008, net government debt as a percentage of GDP plummeted. As a result, 
government net worth has increased dramatically. This fiscal consolidation was part of a package of economic reforms initiated since 1984, which, along with improvement in the external trading environment (including the rise of the Asian economies), caused the 'faster growth (steeper upward trend) from the early 1990s to 2010' in New Zealand's GDP per capita (Lattimore and Eaqub 2011: 7). This renewed economic growth is in marked contrast with the period of poor economic performance and relative economic decline from the mid-1970s to the early 1990s.

The exception to the pattern of fiscal consolidation was the period after the GFC and the Canterbury earthquake sequence, shown in Figure 18.2. Undoubtedly, this period was part of the success of the FRA. At the technical level, the buffer created by low public debt meant the government had the fiscal space to achieve broader stabilisation objectives in more difficult times. At the political level, the GFC, the Canterbury earthquakes and the 2016 Kaikoura earthquake have also helped cement the cross-party political commitment to fiscal discipline. A series of major external shocks, along with more minor shocks, such as severe droughts and biosecurity scares, helped to remind policymakers of New Zealand's economic vulnerability.

The sustained commitment since the early 1990s to prudent fiscal management by successive National Party governments (shown in blue in Figures 18.1 and 18.2) and Labour-led administrations (shown in red) means New Zealand now has one of the lowest public debt to GDP ratios in the OECD. While other factors, discussed in more detail below, underpinned the cross-party political commitment to fiscal responsibility, the transparency of fiscal forecasts required by the $F R A$ had an important role to play in cementing in prudent fiscal management. The FRA provided the foundations for the fiscal management regime. This helped keep fiscal strategy issues on the political agenda, buttressed the Treasury's fiscal management approach and provided an independent scoring mechanism, which increased the credibility of political commitments to fiscal responsibility.

At the process level, the FRA was a success, as the policy design process resulted in an innovative approach to the fiscal constitution based on principles of fiscal responsibility rather than legislatively fixed fiscal targets. Buckle (forthcoming) describes how 'New Zealand was a pioneer in the development of governance arrangements to improve fiscal transparency in order to strengthen fiscal accountability' and was followed by other 
countries including Australia, with its Charter of Budget Responsibility Act 1998 (Cwlth), and the United Kingdom, with its Charter for Budget Responsibility (2011).

Two principles stand out for the attention they receive in New Zealandnet debt reduction and maintaining an operating surplus - while the other principles have not achieved the same traction. This approach generally proved easy to implement as the FRA was largely codifying the Treasury's budgetary practice of the time and successive ministers of finance have found it a useful device for managing the Cabinet through the Budget process. After 25 years, the principles still provide the framework the Treasury uses to guide the development of the fiscal strategy and the 'rules of the game' under the fiscal management approach (Lomax et al. 2016). By contrast, the 40-year fiscal and economic outlooks introduced into the FRA in the 2004 legislative reforms have had little direct impact on political discourse.

At the political level, the concept of fiscal responsibility-in particular, the focus on net debt and operating surpluses - has been adopted by the main political parties across the spectrum. This was epitomised during the 2017 election campaign when the opposition Labour and Green parties signed an electoral pact that included Budget responsibility rules that were aligned with the provisions of the FRA. Fiscal responsibility is now deeply embedded in the everyday political discourse. When the FRA was introduced, there was limited opposition but widespread scepticism about whether it would have much impact. Support for the FRA is much stronger and more widespread now than at the time of its introduction. Thus, it has proved to be an enduring policy success.

This political success is striking given the FRA was developed by the then National Government through a very top-down policy process within the executive branch, with no public or cross-party engagement before consideration by the select committee. Just how fiscal responsibility has become an integral part of everyday political discourse backed by a multiparty consensus will be explored in the next section of this chapter.

New Zealand has no single constitutional document, so its constitutional arrangements can be found in a range of places. While it has no prescriptive legal status, the Cabinet Manual itself is regarded as an authoritative description of New Zealand's constitutional conventions and statutes. In the introduction to the Cabinet Manual, Sir Kenneth Keith (2017), 
one of New Zealand's leading jurists, explicitly mentions the Public Finance Act as one of the statutory sources of the New Zealand constitution. Then finance minister Sir William English, when introducing the 2013 FRA amendment said: '[G]iven the constitutional significance of the fiscal responsibility provisions, it was important that we discussed the changes with other parliamentary parties before introducing them to Parliament' (quoted in Lipski 2015: 8). As such, the fiscal responsibility provisions in the Public Finance Act now form an integral part of New Zealand's Constitution.

Box 18.2 and Figure 18.2 show how the FRA has endured through three long-running administrations, one major recession (2006-09) and the major fiscal shock of the Canterbury earthquake sequence (9-10 per cent of GDP). The imprimatur of fiscal responsibility is very important for all the major and minor parties on both the left and the right, as evidenced by the 2017 Labour-Green agreement on Budget responsibility rules. The absence of a large and strong populist party with no concern for long-term fiscal prudence has helped, as has the absence of a 'Tea Party' type conservative party committed to low taxes but not necessarily lower expenditure.

\section{Box 18.2 Fiscal Responsibility Act timeline}

January 1993: Finance minister Ruth Richardson summons the outgoing Treasury secretary and Treasury officials to a retreat.

Early 1993: The Treasury provides a stream of advice to the Minister of Finance to develop a regime based on fiscal responsibility principles rather than legislated fiscal targets, leading to a Cabinet paper.

Mid-1993: Cabinet approves the policy and subsequently the draft legislation.

September 1993: Fiscal Responsibility Bill introduced to parliament.

October 1993: First preelection economic and fiscal update published.

November 1993: General election, with the National Party returned with a significantly reduced majority; the majority in the referendum favours a new mixed-member proportional (MMP) system over the traditional first-past-the-post (FPP) system. Ruth Richardson is replaced as finance minister, does not take up another Cabinet position but is appointed chair of the Finance and Expenditure Select Committee (FEC).

Early 1994: The FEC considers the Fiscal Responsibility Bill. There is limited opposition but only lukewarm support, as there is widespread scepticism about whether it will have much impact (Scott 1995).

April 1994: Select committee report reflects bipartisan support for the general thrust of the Bill but a split over whether fiscal responsibility principles should be legislated (favoured by the government majority) or left to the government of the day (favoured by Labour). 
May 1994: The Budget includes a dry run of the operation of the FRA, including a fiscal strategy report.

1 July 1994: The FRA assent comes into force.

May 1995: First Budget under the FRA.

October 1999: Election of the fifth Labour-led government, headed by Helen Clark.

2004: An omnibus public management reform Bill is introduced that makes three major amendments to the FRA, as well as some minor technical changes:

- the FRA is folded into the Public Finance Act

- the Treasury is required to provide economic and fiscal projections with a 40-year horizon every four years

- clarification is made that the focus of the Budget policy statement will be the broad fiscal parameters and priorities, to more clearly differentiate the contents of the statement from the more detailed discussion in the fiscal strategy report.

November 2008: Election of the fifth National Party-led administration, under the leadership of John Key.

2013: Amendments to the Public Finance Act fiscal responsibility provisions change the tax policy principle and include additional principles:

- the interaction between fiscal and monetary policies

- the likely impact of any fiscal strategy on present and future generations

- the effectiveness and efficiency in management of the Crown's resources.

February 2017: The opposition Labour and Green parties commit to Budget responsibility rules.

September 2017: The sixth Labour-led administration elected, headed by Jacinda Ardern.

In this chapter, the story of the design, rollout and increased acceptance of the FRA is explored by drawing on the available literature as well as through the words of its designers and implementers. A qualitative methodology was adopted, based on a literature scan and semistructured interviews with the key decision-makers who were directly engaged in the FRA. The interviews included two former Treasury secretaries, a former finance minister, a former budget director and the current chief accounting advisor.

The remainder of the chapter will explore how fiscal responsibility has become an integral part of New Zealand's constitutional arrangements and is now a part of everyday political discourse. It will discuss how the success reflects a combination of careful policy work by the Treasury for the initial political champion, sustained support from successive ministers of finance and some fortuitous circumstances that helped cement the regime. 


\section{The contextual imperative}

In early 1993, when the FRA first emerged as a fiscal policy initiative, New Zealand was into the eighth year of the most wrenching and wideranging reform program undertaken by any OECD country. Only the countries of Eastern Europe-emerging from four decades of communist rulehad been through more extensive change (see Chapter 15, this volume). This reform program was a reaction to the excesses of the Muldoon National Government (1975-84), which had introduced an increasingly unorthodox style of economic management following a period of sustained poor economic performance and economic stagnation. The policies of the Muldoon Government had culminated in an 18-month wage and price freeze underpinned by a reported fiscal deficit that grew to 9 per cent of GDP (7 per cent of GDP on a basis comparable with other statistics in this chapter). Sustained structural fiscal deficits had resulted in public debt growing from about 5 per cent of GDP in the early 1970s to about 45 per cent of GDP by 1984 (shown in Figure 18.1).

Reformist governments - first under Labour (1984-90) and then under National (1990-99) — set about addressing the structural imbalances that had developed over the previous decades, including turning around the fiscal balance and reducing public indebtedness. The incoming National Government in 1990 faced the unpleasant surprise of a deteriorating fiscal outlook, which was accentuated by the need to bail out the failing Bank of New Zealand. In opposition, it had based its election commitments on the Budget forecasts, which were much more benign. In response, in the December 1990 statement and the 1991 Budget, the National Government had to abandon most of its preelection manifesto and instead introduced 'the mother of all Budgets'. This announced wideranging spending cuts and social policy reforms, including reductions in social welfare benefit payments. Public disquiet with the reform programs of both major parties was growing and political polls showed people favoured a new mixed-member proportional (MMP) representation system over the traditional first-past-the-post (FPP) system. An indicative referendum in 1992 signalled a change to the electoral voting system, which a binding referendum combined with the 1993 election was expected to confirm. 


\section{Political champion}

The political champion for the FRA was the finance minister Ruth Richardson, who tasked the Treasury with developing a fiscal analogue to the Reserve Bank Act. Whereas monetary policy is essentially technical, fiscal policy is inherently political, as the Budget is an overt expression of the government's priorities.

The immediate political driver for the minister's request was the fiscal position National inherited on taking office in 1990, together with the threat of a change to the MMP system in 1993 and the view that minority and coalition governments were prone to weak fiscal control and deficit spending. The other driver was New Zealand's recent experience of fiscal deficits and the political costs of deficit reduction. The minister wanted to leave a legacy so that no Minister of Finance would go through what she (and previous Labour finance ministers) had been through. In this, she was supported by the prime minister, who was concerned to ensure that future governments should not expect the unpleasant fiscal surprise that their administration had inherited.

Box 18.2 includes a chronology of events leading up to the enactment of the FRA and beyond. It shows that, while National was returned to office after the 1993 election, it was with a significantly reduced majority. Richardson, when replaced as the Minister of Finance, did not take up another Cabinet position but was appointed as chair of the Finance and Expenditure Select Committee (FEC). As the chair of the committee considering the Fiscal Responsibility Bill, she could drive it through the parliamentary process to enactment. Shortly thereafter, Richardson resigned from parliament and left politics.

\section{Bureaucratic steward}

If Richardson was the political champion for the introduction of the FRA, the Treasury was the bureaucratic steward. While the Minister of Finance was initially attracted by the US style of legislated fiscal rules setting targets for spending, deficits and debt, Treasury officials were very sceptical about legislated targets in fiscal constitutions. This scepticism was based on an understanding of a range of countries' experiences and the US experience particularly with the Gramm-Rudman-Hollings Balanced 
Budget Act. (The Treaty on European Union-or Maastricht Treatywhich introduced statutory deficit and debt limits, and which came into force in 1993 as the FRA was being developed, did not significantly influence official thinking in New Zealand as there was no experience on which to draw.) Treasury officials, however, had positive experiences with increased fiscal transparency over the period of the reforms, which suggested that transparency could be a very effective fiscal tool. In 1992, the Treasury had been able to release a set of unqualified consolidated Crown accrual accounts that covered the wider state sector using GAAP. The resulting information was influential in avoiding a double downgrade by the international credit rating agencies.

The FRA, based on transparency about fiscal responsibility principles and a medium-term focus, offered a number of technical opportunities to:

- lock in good budgetary practices moving from one-year Budgets to disclosure of three-year fiscal forecasts - practices that emerged during the reform era but were not always observed

- clarify roles to ensure the independence of the Treasury in preparing economic and fiscal forecasts

- enable the Budget to be driven by generally accepted accounting practices based on independently set accounting standards and to move away from the previous cash accounts (so-called Table 2), which were riddled with inconsistencies in treatment and had lost credibility

- strengthen the public sector management reform agenda through cementing the use of GAAP

- provide a commitment device to redress the time inconsistency problem by highlighting the future consequences of current policy settings

- increase the credibility of fiscal policy, using transparency to help shape expectations and hence reduce the risk premiums on public debt

- introduce a stronger top-down discipline on fiscal policy, giving up control of the little numbers to get control of the big numbers (to paraphrase the words of the Secretary of the Treasury).

Richardson, a powerful politician championing the $F R A$ - first as the Minister of Finance and then as chair of the FEC-with active backing from the prime minister, put the FRA on the political agenda and kept the Bill moving through the legislative process with the Treasury's support. 
There was no overt program to build support for the FRA. When it was introduced, the FRA received limited opposition but only lukewarm support. Early on, opposition politicians thought the legislation would be ineffectual because of its unenforceability. Lipski (2015: 8) quotes Winston Peters's speech to the House, in which he said: '[L]egislation of this type in this country is meaningless unless this Parliament means to keep faith with the public.' In a similar vein, Michael Cullen-who would become finance minister in the Clark administration-called the FRA 'constitutional nonsense' and suggested the 'notion that this Parliament will somehow bind future Governments on fiscal policy by stating such matters as it must "maintain a fiscal surplus in any year", is constitutional stupidity' (New Zealand Parliament 1994a: 225). Paul Swain-later a senior minister in the Clark Government—suggested it is neither possible nor desirable for this Government to try legislatively to "strait-jacket in" policy directions in the area of fiscal policy for future Governments' (New Zealand Parliament 1994b: 610.

However, leaving aside point-scoring in parliamentary debates and quibbles over the legislation binding subsequent parliaments, the FRA could build on a bipartisan political consensus that supported fiscal prudence. With a strong political champion, the Bill became law.

The new regime initially attracted favourable international attention. As Lipski (2015: 7) observed:

\begin{abstract}
When introduced in 1994, the provisions were seen as world-leading and influential institutional reform. They have been cited as best practice by international agencies such as the Organisation for Economic Cooperation and Development and the International Monetary Fund. (see also, for example, IMF 2007)
\end{abstract}

The continued external support is reflected in the 2013 'National Integrity System Assessment' conducted by Transparency International.

\title{
Policy design from the top down
}

The policy design process was remarkably quick by contemporary policy standards-from conception to enactment in less than 18 months. Consistent with the modus operandi at the time, it was a top-down process driven by the finance minister, with the full backing of the prime minister and supported by the Treasury. The policy design encountered few 
challenges within the government and limited interest and little sustained opposition when introduced into the House. The rollout was similarly uncontroversial, as the approach was technically easy to implement. The FRA was essentially codifying the approach already adopted in the 1994 Budget. The chain of events from conception in January 1993 through to application in the May 2018 Budget is shown in Box 18.2.

Looking at the sequence of events between conception of the idea in 1993 and enactment of the Bill in June 1994, a number of things deserve comment:

- Speed of design: New Zealand politicians have a reputation for being 'the fastest law-makers in the West' (Palmer 1979: 77). In this case, the elapsed time from conception to enactment was less than 18 months, and that included a general election after introduction but before select committee consideration of the Fiscal Responsibility Bill. While rapid, the time required was not unprecedented, as the style of the government of the day was to execute priorities quickly.

- Top down and executive driven: The initiative for the FRA came from the Minister of Finance, who requested the Treasury in January 1993 design the fiscal policy equivalent to the Reserve Bank Act for monetary policy independence. A small Treasury team, working closely with the Minister of Finance, then presented a stream of advice that culminated in the Fiscal Responsibility Bill, introduced to the House in September 1993.

- The lack of challenge: While within the executive there were critical voices (the Ministry of Justice had concerns about parliament legislating the executive's Budget process), there were no significant challenges. Similarly, once in the House, there was little sustained comment or opposition (unlike, say, the challenge raised to the proposals for the Regulatory Responsibility Bill in 2010).

- Bipartisan consensus on fiscal responsibility as a concept: The opposition supported the broad thrust of the FRA on introduction but thought it would be ineffective in practice. 


\section{The rules of the game}

Under New Zealand's political rules of the time, political power was extremely centralised. With a single House, an FPP electoral system, the Westminster system of Cabinet collective responsibility and two wellestablished and strongly disciplined dominant parties, New Zealand's system was described not unfairly as 'an elected dictatorship' (Palmer 1979: 10). With a forceful finance minister, backed by the most powerful government department and with the prime minister's active support, legislative change was reasonably easy to achieve.

The institutional feature that constrained that 'unbridled power' was the fact that New Zealand's Treasury had a strong tradition of having a view independent of its minister. The initiative for the $F R A$ came from the Minister of Finance, who had in mind a regime of legislated fiscal targets and rules similar to those used at the state and federal levels in the United States. The Treasury assembled a small, focused team to respond to the minister's request. The advice it provided concluded that legislated fiscal targets and rules had proved singularly ineffective in a wide range of jurisdictions. To quote from recent work by the Cato Institute:

[T]argets will be missed or abandoned, creative accounting and overoptimistic forecasts will be used to hit targets, exceptional needs for spending will be declared, and transition periods to hit targets will be lengthened. (Bourne 2018: 6)

Instead, the Treasury proposed an innovative approach based on transparency about the principles of fiscal responsibility and independent forecasts and accounts. As one official observed:

Essentially debt and surplus targets are required to be committed to by the government of the day, and that's a harder target to miss or abandon than one that has been set for you by others.

This approach was accepted by the government and continues to set the framework for fiscal policy in New Zealand today.

What is meant by fiscal rules is there are set numerical targets or limits on the Budget balance, debt, spending and tax revenue. These rules operate within a framework of a more general fiscal constitution set out in the Public Finance Act, Standing Orders and the Cabinet Manual and related documents. Examples of such rules include: 
- Those that make the decisions of the Executive government are subservient to those of Parliament in a unicameral system, and/or of a second chamber in the case of a bicameral government

- The principle that Parliament will not delegate the power to tax

- The rule that government money cannot be spent except in accordance with parliamentary appropriations

- Rules relating to voting arrangements on fiscal matters. (Wilkinson and Acharya 2014: 53-4)

These general Budget rules also form an important constitutional context for the operation of the FRA.

\section{Implementation by the executive}

The FRA, once enacted, proved relatively easy to implement as it was largely codifying the Treasury's budgetary and accounting practices of the time. The accounting infrastructure introduced by the 1989 Public Finance Act could be applied to fiscal decision-making and accountability. The 1994 Budget was used as a dry run, so when the FRA came into force for the 1995 Budget, it was business as usual. Piloting was not essential to the success of the policy, but it did reinforce the case for enacting the FRA. The Treasury did, however, have to introduce a new information technology (IT) system as the old Budget management system lacked the required functionality to support the monthly fiscal reporting of progress against Budgets and forecasts required by the FRA.

Budgeting is a technical process that serves a political purpose. Successive ministers of finance under Labour and National-led administrations found the transparency and disclosure requirements of the FRA a useful discipline to tame the spending aspirations of their Cabinet and caucus colleagues.

It is instructive to compare the traction the principles for the operating balance and net debt have achieved with the lack of any direct impact of the long-term fiscal statement. The latter was introduced in the 2004 amendments to the FRA and required the Treasury to produce 40-year economic and fiscal outlooks every four years. There was no dry run prior to the introduction of the long-term fiscal statement, no requirement for the government to formally respond and limited direct political use for the projections. Unlike the four-year fiscal strategy, for which the 
government sets formal targets and the Treasury reports against those goals, the 40-year fiscal projections stand in splendid isolation. As one former Treasury official observed: 'We legislated before we knew what it was' and 'we still don't know what a good 40-year fiscal forecast looks like.' The Office of the Auditor-General was similarly polite but scathing in its recent performance audit of the 2016 statement on New Zealand's long-term fiscal position (OAG 2017).

There are three parts to New Zealand's Budget system:

1. the FRA principles, which provide the foundation

2. the annual BPS and fiscal strategy of the government of the day, along with supporting material prepared by the Treasury on the fiscal and economic outlooks, which provide the structure

3. the fiscal management approach of the Treasury, which operationalises these fiscal principles and strategies.

The FRA principles have been discussed above and are outlined in Box 18.1. While these provide a foundation, it is up to the government of the day to articulate how it proposes to operationalise the principles. Box 18.3 compares the Budget responsibility rules used by the Labour-led administration in the 2018 BPS with the corresponding statement of the previous National-led administration in 2017.

\section{Box 18.3 Comparison of Budget responsibility rules}

Reducing net debt to 20 per cent of GDP within five years of taking office and maintaining at prudent levels thereafter (later than in the 2017 Budget policy statement).

Running sustainable operating surpluses across the economic cycle (no change from 2017).

Maintaining expenditure within the recent historical range of spending to GDP ratio (2017: over time, core Crown expenses are reduced to below 30 per cent of GDP).

Ensure a progressive taxation system that is fair, balanced and promotes the longterm sustainability and productivity of the economy (2017: pursue policies consistent with reasonable stability and predictability of tax rates).

The government will strengthen net worth consistent with the debt and operating balance objectives (2017: ensure net worth remains at a level sufficient to act as a buffer to economic shocks).

Prioritise investments to address the long-term financial and sustainability challenges facing New Zealand (no direct counterpart in the 2017 BPS, which did include: manage prudently the fiscal risks facing the government). 
One of the key features of the 2018 BPS is that only two of the fiscal aggregates are expressed as measurable targets: the operating balance and net debt. Successive administrations have committed themselves to running fiscal surpluses (operating surpluses across the economic cycle). There is a longstanding cross-party consensus on the need to reduce public debt. Both major parties are currently committed to reducing net debt to below 20 per cent of GDP; the only point of difference is the timing.

There has been much less traction with the principles relating to tax, risk and net worth. Although there have been fewer surprise announcements of tax changes, there is no evidence that the FRA tax principles have had any practical effect, and the lack of commentary on the changes to the tax principles (shown in Box 18.3) reinforces this. Ministers of finance are answerable for the operating balance of taxes and spending (before accounting gains and losses) but there has been much less focus on change in net worth. The government's investment statement, introduced by the 2013 amendments to the Public Finance Act, has attempted to increase the focus on the Crown's management of its balance sheet but so far with limited success. The risk principle is operationalised in the Budget economic and fiscal update, with a detailed discussion of the key risks facing the economy (including two alternative scenarios) as well as disclosure of specific fiscal risks (both quantified and unquantified). As the Treasury secretary has statutory independence on the preparation of this material, the effect is to reinforce the integrity of the fiscal forecasts. Arguably, the increased transparency also encourages governments to address the risks that may hit them in the near future by taking action earlier.

To give effect to the government's fiscal strategy, the Treasury has developed a fiscal management approach. The key features of this approach were developed in the 1990s; it was fully formed in the early 2000s and is still applicable today. The approach includes:

- fixed nominal baselines with no allowance for inflation

- operating allowance for new initiatives (on a net basis) with limited exclusions such as debt servicing and major accounting gains or losses

- capital allowances for new financial or major physical investments

- technical forecasting changes including the operation of automatic stabilisers through welfare benefits and tax revenue changes, as well as New Zealand Superannuation 
- fiscally neutral changes, which can be agreed within the financial year

- Contingencies for between-Budget baseline changes.

As one of the FRA's architects commented, 'the Act codified and embedded an emergent culture'. This culture in turn reflected a wider cross-party consensus on the imperative for greater transparency and fiscal responsibility. The FRA likely also represented a return to the culture of fiscal conservativism in New Zealand that had existed until the 1970s.

In a regulatory impact statement in support of the 2013 Public Finance Act amendments, the Treasury said:

There is no legal sanction for breaching the provisions, and it would also be possible for a government to comply with the form of the provisions but not their substance. The success or otherwise of the fiscal responsibility provisions therefore depends on the level of acceptance and support they receive across government. (The Treasury 2012: 1; emphasis added)

Put another way, the FRA has political force even if it is not legally enforceable.

\section{Parliament largely absent}

The discussion to date has focused on how the executive has implemented the FRA. We turn now to the legislature, as a key part of the design was increased scrutiny by parliament. The FRA provides for a BPS for parliament to scrutinise how the government proposes to operationalise the fiscal responsibility principles. The BPS is generally provided in February—well in advance of the Budget (in May).

In practice, the select committee's reviews of the BPS have rarely been very enlightening or insightful. The size of the New Zealand Parliament, unlike its British parent, is too small for politicians to make a career leading the work of select committees. As one interviewee observed:

The role of a unicameral parliament in our version of the Westminster system is to focus on lawmaking not scrutiny. To the extent it is involved in scrutiny, it has been down in the weeds (the standard estimates questionnaire of inputs and individuals' expenses) rather than in the sky focusing on the big picture of fiscal strategy. 
This is consistent with Mark Prebble's 'iron rule of political contest', which can be defined as 'the opposition in parliament does not criticise the government to improve it; they criticise it to lawfully overthrow it' (Prebble 2010: 35-8). Unless the BPS provided an opportunity for the opposition to attack the government, the standard and level of scrutiny would not be high.

The transparency, quality and multiyear focus of the fiscal information have been useful to the Controller and Auditor-General in providing the context for parliamentary briefings and for the opposition in helping them shape their policy platform. The FRA has been successful in ensuring that no incoming government has experienced the unpleasant fiscal surprise that faced the 1990 National Party administration.

\section{Monitoring by commentators and capital markets}

Parliamentary monitoring, by analogy with policing, was based less on regular patrols than on waiting for alarms to go off. The Treasury, in its role as the independent and credible scorekeeper, was an important source of information to trigger the alarms. Economic commentators and financial market analysts are both active users of that financial information who can then sound the alarm.

As one of the architects of the FRA told the author:

One clear consequence of financial market reforms was the speed at which markets would respond to poor policy and, in particular, to poor fiscal policy. The aggregate fiscal policies of governments were closely assessed by financial analysts and could be quickly reflected in interest rates. The discipline being imposed by financial markets has played quite a significant role in supporting much better fiscal policy and transparency.

Political commentators and economic analysts (such as bank economists) were also actively scrutinising the fiscal information for inconsistencies with the 'Wellington consensus' on the importance of prudent fiscal management.

\section{Gaining broad acceptance}

Fiscal policy has become part of the wider political discourse as parties compete for the 'fiscal responsibility' mandate. Parties across the political spectrum put considerable effort into costing their preelection policies. 
As discussed above, the electoral agreement between the opposition Labour and Green parties on Budget responsibility rules has flowed directly into the 2018 BPS and Budget documents. Following the release of the 2018 Budget, the National Business Review, New Zealand's leading business journal, featured a lead article with the headline: 'Well-being budget will put pressure on budget responsibility rules' (Edwards 2018). There are dissenting voices suggesting the FRA provisions are a 'false idol' (Nana 2017) or a 'straitjacket' (Eaqub 2018). The more widespread view is that it is a useful addition to the public management system and provides a framework that can be used to assess other target-setting regimes such as the Child Poverty Reduction Bill (Easton 2018).

\section{Durability in the face of fluctuations}

One of the key dimensions of policy success is how well the policy regime endures over time following political changes in administrations and in the face of economic expansions and contractions. Figure 18.1 shows how successive National and Labour-led administrations before the GFC ran sustained structural surpluses, driving down the net public debt to GDP ratio accordingly. For example, New Zealand ran sustained structural surpluses in the range of 1.5-6 per cent of GDP from 1994 to 2006. Net public debt over the same period fell from just over 60 per cent of GDP to just under 5 per cent. Indeed, the ratio fell below zero if the New Zealand Superannuation fund is also included.

While it is tempting to attribute that reduction in public indebtedness to the FRA, in fact, the start of the improvement in New Zealand's fiscal position pre-dates its enactment. While the transparency required by the FRA had an important role to play, other factors were more important:

- The legacy of the Muldoon years with a bipartisan political commitment to fiscal responsibility.

- The establishment of the New Zealand Superannuation Fund (the socalled Cullen Fund) to partially prefund the increased future cost of the New Zealand Superannuation pension, due to population ageing.

- The increasing recognition of the importance for a small trading nation of fiscal resilience and sustainability. 
The FRA, while not the catalyst, helped cement fiscal discipline into the political discourse and budgeting practice in New Zealand. As one interviewee observed: 'It is less about whether the FRA helped achieve a better fiscal performance, and more about whether it helped sustain it.'

Fiscal strategy needs to focus on short-term macroeconomic stability as well as medium-term fiscal sustainability. One of the criticisms of the Fiscal Responsibility Bill in the select committee was that the medium-term focus would constrain the government from undertaking an anticyclical fiscal policy, beyond the operation of automatic stabilisers. These fears have proved unjustified. If anything, the opposite has occurred, as New Zealand has experienced some of the biggest swings in the OECD in its structural fiscal balance.

The Treasury's analysis suggests the FRA framework, while focusing on medium-term fiscal sustainability, places little attention on shorter-term macroeconomic stability, such as the impact of procyclical increases in government spending. Brook (2013: 71) suggests:

New Zealand's current fiscal policy framework-with its emphasis on a debt target—gives insufficient emphasis to macro stabilisation during upturns in the business cycle, especially once the debt target has been met. In a small open economy such as New Zealand, with a floating exchange rate, pro-cyclical fiscal stimulus is unlikely to have much impact on aggregate demand (because of leakage into imports and the offsetting impact of tighter monetary policy), but it does have a significant impact on the mix of macro-economic conditions. Higher real interest rates, and associated exchange rate appreciation, is [sic] unhelpful to an economy already experiencing macroeconomic imbalances.

Figure 18.3 compares the cyclically adjusted (or structural) fiscal balance with the output gap. It covers the second and third terms of the Clark Labour-led Government and the first term of the Key National-led Government. $^{2}$

2 For an independent account of New Zealand fiscal policy before the GFC, see Norman and Gill (2010); for an official summary of fiscal policy since the GFC, see Bose et al. (2016); and for a detailed account of the history and evolution of the FRA, including a more technical assessment using the sustainability, stability and structural roles of fiscal policy, see Buckle (forthcoming). 


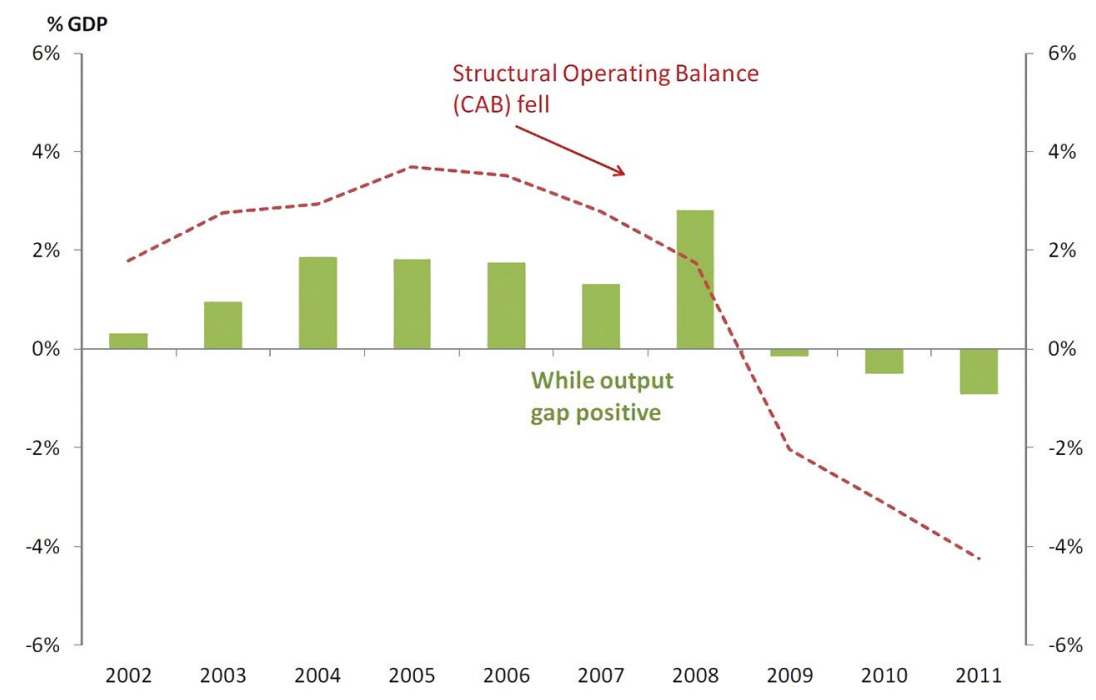

Figure 18.3 Destabilising fiscal stance: The operating balance and the output gap, 2002-11

Source: The Treasury (2012).

In 2008-an election year in New Zealand-there was a marked easing in the stance of fiscal policy despite the output gap still being significantly positive. This reflects windfall gains in taxation revenue, which were used to fund permanent increases in operating spending such as enhancements to the 'Working for Families' policy. The tax revenue increases proved temporary and their reversal coincided with the onset of the GFC and, subsequently, the impact of the Canterbury earthquake sequence (about 10 per cent of GDP over three years). As a result, New Zealand faced a record fiscal deficit of about 9 per cent of GDP in 2011. The framework provided by the FRA meant that, when the National-led administration committed itself to return to fiscal surplus, this was seen as credible and the impact on financial markets was minimised. The government successfully delivered a small fiscal surplus in 2014 (shown in Figure 18.2).

The experience of fiscal management in the face of sustained economic growth led the Treasury to recommend an additional fiscal anchor based on medium-term expenditure or revenue constraints to augment the anchor provided by debt (The Treasury 2008), and subsequently to develop the case for additional fiscal responsibility principles, which were introduced in 2013 (included in Box 18.1). Figure 18.3 is drawn from the Treasury's regulatory impact statement for the 2013 amendments to 
the fiscal responsibility provisions in the Public Finance Act. It is difficult to discern any impact from the 2013 amendments. For example, it is not clear whether the three new principles informed the 2018 BPS and the fiscal strategy report, and the lack of explicit mention has not attracted unfavourable comment.

\section{The endurance of fiscal transparency and responsibility}

New Zealand's generally positive experience with the FRA contributing to sustained surpluses and debt reduction is consistent with the old saying about 'good things taking time'. When the FRA was introduced, there was limited opposition but widespread scepticism about whether it would have much impact. Support for the FRA is now much stronger than at the time of its introduction.

Since its enactment in 1994, the FRA has set the framework within which fiscal policy has been formulated in New Zealand. Its emphasis on the transparency of forecasts has been key to ensuring fiscal responsibility and resilience. The durability of the regime lies in the fact the FRA does not specify, for example, what constitutes a 'prudent level of public debt'. It is left to the government of the day to operationalise what is meant and to disclose this in the annual fiscal strategy report. Similarly, with the notable exceptions of the operating balance rule, net worth and net debt, the other fiscal aggregate principles are qualitative and not readily measurable, leaving the interpretation to the government of the time.

The flexibility of this approach allows the framework to adapt to changing circumstances (the Canterbury earthquake sequence and cyclical fluctuations such as the GFC provide examples from recent history). Arguably, recent shocks have also helped cement the cross-party political commitment to fiscal discipline. This suggests the FRA can remain a success in the future as long as the cross-party commitment to fiscal responsibility is sustained.

New Zealand's experience with a regime based on transparency also speaks to the ongoing debate about fiscal targets and fiscal constitutions. Looking at a range of countries' experiences with entrenching fiscal targets, the Cato Institute concluded: 
The academic evidence and historical record show that formal fiscal rules are neither necessary nor sufficient to obtain sound public finances ... The key is to design rules that are simple enough to be well understood and monitored, but flexible enough to be durable against unforeseen economic shocks that temporarily derail that goal. Doing so requires well thought-through procedural details and means of enforcement. (Bourne 2018: 6)

The enduring and increasing success of the FRA has several unexpected features:

- An apparently weak instrument proved politically powerful when backed by an independent and credible scorekeeper and monitoring by financial markets and commentators.

- Policy success is very path dependent: that the FRA has been increasingly influential and adopted by political parties across the spectrum is a result of both careful design and good luck.

- Budgeting is inherently a political statement (as well as a technocratic process), which means that technocratic Budget rules can influence details of how the game is played but do not change the fundamental nature of the political game.

- Ownership of goals matters: the FRA required the government of the day to articulate the fiscal goals. This reduces the amount of cheating and gaming as the government owns the goals rather than having targets set in legislation.

- Widespread consultation and buy-in to the design of a policy regime are not preconditions for success: the FRA was developed by the National Government through a short, very top-down policy process, with almost no public or cross-party engagement before select committee consideration.

- The unexpected and indeed astonishing success of the FRA arose from a technical policy solution providing a valuable political management tool for ministers of finance.

- Transparency about fiscal responsibility is not enough on its own.

The success of the approach, as Teresa Ter-Minassian, former director of the IMF's fiscal affairs department observed, is down to the

quality, comprehensiveness, reliability and timeliness of the budget documentation, to facilitate adequate scrutiny by the Parliament, and by society at large, of the consistency of the Government's fiscal strategy with 
the above-listed principles. Accordingly, New Zealand has pioneered, and refined over the years, comprehensive fiscal reporting requirements, intended to ensure transparency, and to promote time consistency and a broad debate of the fiscal policy choices of successive Governments. (2014: 14)

Equally important is that the ex post financial information is of the same quality as the ex-ante budget information. The FRA is underpinned by a consolidated set of government financial statements that are consistent with GAAP set by an independent accounting standards body. The accounts are prepared by the Treasury. Treasury, as the most powerful government department, is an influential institution in New Zealand in its own right. In the case of the $F R A$, it has been given statutory independence in the preparation of the fiscal forecasts and financial statements. This means, as one interviewee observed, 'that New Zealand has the cleanest set of financial accounts in the west', which are not subject to the accounting fiddles and off-balance-sheet shenanigans seen in other jurisdictions and in New Zealand in the past.

Merely supplying information does not mean it will be used. While the intended demand for financial information from parliament did not eventuate, economic commentators and financial market analysts have been active users of that information. This active monitoring served to reinforce the Minister of Finance's position within Cabinet on the importance of fiscal responsibility.

\section{Unfinished business}

Nonetheless, the framework provided by the $F R A$ is not without potential risks and problems.

The first is that the future durability of the $F R A$ is dependent on popular support for the importance of fiscal responsibility and that cross-party commitment to fiscal responsibility is sustained. To date, New Zealand politics has been notable for the absence of a large and strong populist party with no concern for long-term fiscal prudence or a 'Tea Party' type conservative party committed to low taxes but not necessarily lower expenditure. 
Second, the ongoing integrity of the FRA framework is heavily reliant on the Treasury continuing to actively pursue its stewardship role, including as an independent scorekeeper.

Third, while the FRA provides a useful framework for executive government, the fiscal regime is largely silent on where the other political parties fit. New Zealand is one of the few OECD countries without an independent budget office. While New Zealand's size may mean building an independent economic and fiscal forecasting capability is not realistic, there remains the role of assisting other political parties with costing policy proposals (Wilson 2017). The 2018 Budget announced the government was developing a proposal for an independent budget office, so the gap in the current fiscal framework may be addressed by this initiative.

Fourth, the framework has had limited effectiveness in taking into account the effect of the business cycle. Figure 18.3 shows the changes in the structural fiscal balance, with New Zealand experiencing some of the biggest swings in the OECD. While net debt provides a powerful fiscal anchor for medium-term sustainability, it is less robust for dealing with macroeconomic stability.

\section{Conclusions}

These caveats aside, there are unique factors that could limit how broadly the lessons from this case can be applied. There were both political and technical preconditions that were required to underpin the operation of the FRA. The FRA principles need to be supported at the political level by the commitment of the government of the day to a prudent fiscal strategy and at a technical level by a fiscal management approach to operationalise the government's fiscal strategy.

At the technical level, the FRA was backed by a powerful treasury with a suite of tools and techniques to make the fiscal strategy stick. The FRA gave fiscal policy a top-down discipline for sustaining a long-term regime of fixed nominal baselines, while the financial management reforms delivered the required bottom-up flexibility. As one source commented: 'Introducing the FRA in 1984 simply wouldn't have worked.' 
Without political will, however, the techniques of fiscal management will not deliver fiscal discipline. As the FRA is not legally enforceable, it needs to have political force. Political will is not something that exists in isolation. The ongoing legacy of the Muldoon years is an enduring consensus across the major political parties on the importance of prudent fiscal policy. Financial market and other nonpolitical monitoring processes have helped sustain that political will. The FRA helped to codify and embed into political discourse and budgeting practices a commitment to fiscal prudence and lent credibility to the Budget process. But, without that political commitment, fiscal responsibility principles would have remained just principles, with government statements complying with the form of the provisions but not their substance.

In summary, the $F R A$ was a commitment device that helped cement fiscal discipline into New Zealand's budgeting system and policy discourse rather than the catalyst that started it. In the process, the FRA provides the foundations for the Treasury's budgeting process, is embedded in the wider everyday political discourse and is now part of New Zealand's constitutional framework.

\section{References}

Bose, D., Philip, R. and Sullivan, R. 2016. Returning to surplus: New Zealand's recent fiscal consolidation experience. Treasury Working Paper 16-05, 3 February. Wellington: New Zealand Government. Available from: treasury. govt.nz/publications/wp/returning-surplus-new-zealands-post-gfc-fiscalconsolidation-experience-wp-16-05.

Boston, J. 2016. 'Committing to a better future: The nature, design, and limits of commitment devices.' In J. Boston (ed.), Governing for the Future: Designing democratic institutions for a better tomorrow. (Public Policy and Governance, Volume 25). Bingley, UK: Emerald Group Publishing. doi.org/10.1108/ S2053-769720160000025009.

Bourne, R. 2018. Budget restraints that work: Lessons from Chile, Switzerland, the United Kingdom, and the United States. Tax \& Budget Bulletin No. 81, February. Washington, DC: Cato Institute. Available from: object.cato.org/ sites/cato.org/files/pubs/pdf/tbb-81.pdf.

Brook, A. 2013. 'Making fiscal policy more stabilising in the next upturn: Challenges and policy options.' New Zealand Economic Papers 47(1): 71-94. Available from: ideas.repec.org/a/taf/nzecpp/vv47y2013i1p71-94.html. 
Buckle, B. forthcoming. 'Fiscal policy governance and institutional developments in New Zealand: 1994 to 2018.' In G. Karacaoglu and E. Berman (eds), Public Policy and Governance Frontiers in New Zealand. Bingley, UK: Emerald Group Publishing.

Eaqub, S. 2018. 'The Budget: A delicate dance on a fiscal tightrope.' Stuff. co.nz, 20 May. Available from: www.stuff.co.nz/business/opinion-analysis/ 104012769/the-budget--a-delicate-dance-within-a-straightjacket.

Easton, B. 2018. 'Improving the Child Poverty Reduction Bill.' Pundit, 3 May. Available from: www.pundit.co.nz/content/improving-the-child-povertyreduction-bill.

Edwards, B. 2018. 'Well-being budget will put pressure on budget responsibility rules.' National Business Review, 21 May.

International Monetary Fund (IMF) 2007. Manual on Fiscal Transparency. Washington, DC: IMF. Available from: www.imf.org/external/np/fad/trans/ manual/sec02b.htm.

Keith, K. 2017. 'On the Constitution of New Zealand: An introduction to the foundations of the current form of government.' In Cabinet Manual. Wellington: Department of the Prime Minister and Cabinet. Available from: www.dpmc.govt.nz/our-business-units/cabinet-office/supporting-workcabinet/cabinet-manual/introduction.

Kerr, R. 2008. 'Do economists agree on anything?' NZ Business Roundtable, 1 April. Wellington: New Zealand Initiative. Available from: nzinitiative.org. nz/reports-and-media/reports/do-economists-agree-on-anything/.

Lattimore, R. and Eaqub, S. 2011. The New Zealand Economy: An introduction. Auckland: Auckland University Press. Available from: www.press.auckland. ac.nz/en/browse-books/all-books/books-2011/The-New-Zealand-EconomyAn-Introduction.html.

Lipski, J. 2015. Accountability and the fiscal responsibility provisions of the New Zealand Public Finance Act 1989. LLB (Hons) paper, Victoria University of Wellington, Wellington. Available from: researcharchive.vuw.ac.nz/xmlui/ bitstream/handle/10063/5025/paper.pdf?sequence $=1$.

Lomax, N., McLoughlin, S. and Udy, B. 2016. The New Zealand fiscal management approach. Conference Paper. Wellington: The Treasury. Available from: www.nzae.org.nz/wp-content/uploads/2016/10/3228152_ FINAL-Conference-Paper-Guide-to-NZs-FMA.pdf. 
Nana, G. 2017. 'Has fiscal responsibility become a false idol?' Pundit, 26 April. Available from: www.pundit.co.nz/content/has-fiscal-responsibility-becomea-false-idol.

New Zealand Government 2018. He Puna Hao Pātiki: 2018 investment statement. Wellington: The Treasury. Available from: treasury.govt.nz/publications/ investment-statement/2018-investment-statement.

New Zealand Institute of Economic Research (NZIER) n.d. Data1850. [Online]. Wellington: NZIER. Available from: data1850.nz.

New Zealand Parliament 1994a. New Zealand Parliamentary Debates (26 May), 540, 225.

New Zealand Parliament 1994b. New Zealand Parliamentary Debates (7 June), 540, 610 .

Norman, R. and Gill, D. 2010. 'Budgeting in New Zealand after the reforms: From radical revolutionary to cautious consolidator.' In J. Wanna, L. Jensen and J. de Vries (eds), The Reality of Budgetary Reform in OECD Nations: Trajectories and consequences. Cheltenham, UK: Edward Elgar. doi.org/10.4 $337 / 9781849805636.00012$.

Office of the Auditor-General (OAG) 2017. Commentary on He Tirohanga Mokopuna: 2016 statement on the long-term fiscal position. Wellington: OAG. Available from: www.oag.govt.nz/2017/long-term-fiscal-position/docs/longterm-fiscal-position.pdf/view.

Palmer, G. 1979. Unbridled Power? An interpretation of New Zealand's constitution and government. Wellington: Oxford University Press.

Prebble, M. 2010. With Respect: Parliamentarians, officials, and judges too. Wellington: Institute of Policy Studies.

Scott, G. 1995. 'New Zealand's Fiscal Responsibility Act.' Agenda 2(1): 1-13.

Ter-Minassian, T. 2014. External Review of the Treasury's Fiscal Policy Advice: New Zealand. Wellington: The Treasury. Available from: treasury.govt.nz/sites/ default/files/2014-10/tfpa-2908566.pdf.

Transparency International 2013. New Zealand national integrity system assessment 2013. Integrity Plus 2013. Berlin: Transparency International. Available from: www.transparency.org/whatwedo/publication/new_zealand_national_ integrity_system_assessment_2013. 


\section{SUCCESSFUL PUBLIC POLICY}

The Treasury 2008. Briefing to the Incoming Minister of Finance: Economic and fiscal strategy_Responding to your priorities. Wellington: New Zealand Government. Available from: www.beehive.govt.nz/sites/default/files/Treasury2_BIM_0.pdf.

The Treasury 2012. Amendment to part 2 of the Public Finance Act 1989 (the fiscal responsibility provisions). Regulatory Impact Statement. Wellington: The Treasury. Available from: treasury.govt.nz/sites/default/files/2012-08/ristsy-pfafrp-aug12.pdf.

The Treasury 2018. Budget 2018. Wellington: The Treasury. Available from: treasury.govt.nz/publications/budgets/budget-2018.

Wilkinson, B. and Acharya, K. 2014. Guarding the public purse: Faster growth, greater fiscal discipline. Report. Wellington: New Zealand Initiative. Available from: nzinitiative.org.nz/reports-and-media/reports/guarding-thepublic-purse/.

Wilson, P. 2017. Keeping the bastards honest. NZIER Insight 72. Wellington: New Zealand Institute of Economic Research. Available from: nzier.org.nz/ media/keeping-the-bastards-honest-nzier-insight-72. 
This text is taken from Successful Public Policy: Lessons from Australia and New Zealand, edited by Joannah Luetjens, Michael Mintrom and Paul 't Hart, published 2019 by ANU Press, The Australian National University, Canberra, Australia.

doi.org/10.22459/SPP.2019.18 